\title{
Conquest, Domination and Control: Europe's Mastery of Nature in Historic Perspective
}

\author{
Philipp Pattberg* \\ Vrije Universiteit \\ Amsterdam, the Netherlands
}

\section{Introduction}

Globalisation is increasingly analysed as an historic phenomenon; it has a history, and it is a phenomenon that is capable of making and shaping history. This article attempts to contribute to a broadening of the globalisation research agenda by analysing the ideology of domination and control over the natural environment, one of the fundamental ideological underpinnings of our current global transformation, in a historical perspective. The paper serves two purposes. First, by analysing the history of fundamental ideologies such as the domination of nature, this article places current social practices within the larger framework of historic dynamics of globalisation. Second, by analysing the ideological underpinnings of global transformations, it sheds light on the co-construction of social order through the development of material and ideational realms. Alternative approaches towards globalisation research should include analysis of the ideology of "mastery" over nature. The perspective chosen in this article can be characterised as historical political ecology, because it centres on a critical assessment of the interaction of political, social and environmental variables in a historic perspective (cf. Greenberg and Park 1994), in this case offering comparison between Europe and China.

"Breathless and fragmented, the world rushes into the new millennium". This is the message that the German Advisory Council for Global Environmental Change (Wissenschaftlicher Beirat der Bundesregierung Globale Umweltveränderungen, WBGU) places at the beginning of its annual assessment for the year 2000 (2001: 13). And indeed, the state of the world's environment is represented as one of constant crisis and turmoil, despite the plethora of environmental regimes and organizations working towards the amelioration of this crisis. Total global fossil fuel consumption (coal, oil and natural gas) rose to a new peak of 7,956 million metric tons of oil equivalent in 2001. Carbon dioxide emissions reached 6,553 million tons in 2001, amounting to a record concentration of 384 ppm carbon dioxide in the atmosphere (measured at the Mauna Loa Observatory, Hawaii, 2007). The capacity of the 436 nuclear reactors operating in over 35 countries has reached 351 gigawatts and the economic mega-machine on which all these achievements rest, produced a record annual gross world product of US \$40.5 trillion in 1999 (1998 prices). The flipside of this steady economic growth is a global environment deteriorating at an accelerating rate, and human societies suffering continuing violent upheavals. There were over 150 major and minor armed conflicts between 1990 and $2000 .^{1}$

Over the course of human history, humankind's impact on its natural environment has magnified, including its ability to alter, shape and reshape nature, its abilities to dominate the global environment in all its forms and to construct it according to its own needs. The ideology that provides for this unprecedented enterprise - the mastery of nature - is of European origin, although today it is shared by almost every society on earth, through the subtle effects of globalisation.

This article tries to answer the question why Europe developed an ideology of conquest and domination towards nature and how it achieved the necessary technologies, tools, mentalities, beliefs, institutions and mental frameworks to put this ideology into practice. Why was Europe, a backward region of civilisation up to the late Middle Ages and the Renaissance, able and willing to follow this destructive path with such stubbornness and ingenuity? My ambition in this respect is rather modest. Instead of offering a detailed historical account of the relation between nature and society, I provide a summary of the main trends and issues. This short paper offers a broad and schematic account of European relations to nature, and an interpretation of large-scale historic developments.

The article is organised as follows: section two discusses the difficult relation between humans and their environment, and some features of the historic impacts of human actions. The third section aims at analysing, in a comparative approach, the different parameters that shaped European and Chinese relations towards their natural environment: pre-1500 climate, geography, population,

\footnotetext{
* Philipp.Pattberg "at" ivm.vu.nl. The author is grateful for comments by Mireia Tarradell of the Global Governance Project (glogov.org) and two anonymous reviewers.

$1 \quad$ For more details on the state of the environment see the World Watch Institute's recent report, Vital Signs (2002).
}

Journal of Political Ecology

Vol. 14, 2007 
agriculture, society and culture. ${ }^{2}$ The fourth section focuses on Europe's "step ahead" from China and other civilizations between 1450-1750, and tries to identify the forces that shaped the ideology of "mastery": institutions including the state, the Church, science, capitalism, and events that included scientific discoveries and the Reformation. I conclude with a brief summary of the argument.

\section{The Ideology of Domination: Concepts and Symptoms}

Humans have always shaped and altered their natural environment. ${ }^{3}$ The hunting and gathering activities of tribal societies, agriculture and the domestication of animals in post-Neolithic societies, the construction of the grand canal in classical China, or the ceremonial buildings of MesoAmerican cultures, are different examples of the anthropogenic shaping and control of nature in different historical epochs. The driving force behind most of these actions has simply been the necessity to meet basic needs for food, clothing, housing and to express spiritual beliefs, under the constraint of a steadily growing population (Ponting 1991: 141). Homo sapiens sapiens is the only species that has erected a "second nature" that we term "culture", by an evolving, and eventually decisive alienation of society from the natural environment as part of evolution. ${ }^{4}$ Whether the extensive shaping of natural environments has been a function of "natural evolution", or an artificial "superevolution" is an intriguing debate. The ways in which human beings have constructed their relation to the surrounding world are simultaneously responsible for, as well as serving to legitimize, human impacts on global ecosystems. ${ }^{5}$

The ideology that underpins human mastery and domination over nature is a relative late achievement and, as I will argue, of European origin. ${ }^{6}$ It has developed in the period of Europe's "step ahead" from 1450-1750, closely connected to and mutually influencing the rise of capitalism, the formation of the early modern territorial state, the waning influence of religious dogma, and the emergence of scientific worldviews and discoveries. The "age of discoveries" provided for its worldwide application through travel and exploration, and the French Revolution at the end of the $18^{\text {th }}$ century was a powerful force in the rise of homo economicus and the Industrial Revolution. The ideology of domination "was elevated to the status of a conscious principle for the orientation of human behaviour" (Leiss 1974: xii). It reinforced the separation of society (the sphere of development and meaning), from "nature". The scientific method, emergent in the $17^{\text {th }}$ century, combined an aspiration for a better understanding of "the laws of nature" with the promise of substantial social benefits. The long term effects of this growing scientific understanding of nature were the continued success of scientific discoveries and their technological applications, and an ability to apply technological innovation to mass production, offering hope for the elimination of human misery and social disorder (Leiss 1974: 19). The ideology of the mastery of nature was not simply a function of science and applied technology aided by the economic expansion and political stabilisation of Europe after 1450. It was also the overarching intellectual concept of several discrete or overlapping European cultures that were, at varying speeds and scales, heading towards world domination.

Scientific advance and economic expansion was not confined to European space. They rapidly manifested themselves in places as remote as Siberia and Terra del Fuego. Three different patterns of ecological devastation are most visible in the period between 1450 and 1750 . First, there were species extinctions brought about by overexploitation to meet a growing European market for goods like fur, whale oil and fish. Second, the expansion of the financial system in Europe was responsible in part for the spread of mining activities and advances in hydraulic engineering that had a detrimental effect on the environment. Third, as Crosby (1986) notes, new species were transported and introduced to the ecosystems of the New World and later to other emergent colonial outposts along with European migration, enabled by safer and more reliable ocean transport.

$2 \quad$ China serves as a comparative case because it seemed to possess the necessary conditions for becoming the dominant world civilisation around 1400 but lost its leadership role to Europe (see later discussion).

$3 \quad$ For a detailed account of the human impact on the environment, see Andrew Goudie (2000).

$4 \quad$ By this reading, I do not imply that non-human animals possess no form of social organization (including the ability to learn and to communicate).

Franz Broswimmer (2001) has coined the term "ecocide" for this destructive process, which dates back more than 5000 years. In a similar vein, Chew (2001) argues that the human belief in "exploiting" nature is of a longer duration and has been even more destructive than is frequently acknowledged.

6 This focus on Europe as a driving force in the development and application of a specific ideology of domination should not be equated with unreflexive Eurocentrism.

$7 \quad$ Crosby (1986) uses the term Ecological Imperialism to describe the biological expansion of old world species to the new colonies.

Journal of Political Ecology

Vol. 14, 2007 
In Europe, the extinction or severe impact on species has a long history. The constant need for an extension of arable land to feed a growing population cut into relatively undisturbed habitats, and drove the frontier of European agricultural and pastoral civilisation further and further into the temperate and boreal forests of Central and Eastern Europe. The wolf, the European bison, and the aurochs (the ancestors of modern cattle), were all driven to extinction, or remained only in isolated populations. By the $15^{\text {th }}$ and $16^{\text {th }}$ centuries, state policies tried to limit the negative effects of predator animals and birds on agriculture, by giving incentives to hunters and trappers (Ponting 1991: 164). ${ }^{8}$ Hunting as a "sport" has also contributed to the extent and variety of European wildlife. But it was the discovery of the New World and the newly-won ability to travel by fast, safe, and affordable ocean transport that extended the reach of European market demand for goods like fur, fish and whale oil and sanctioned killing on a massive scale. Exploitation continued at an accelerating pace across the global commons - in the oceans, and the plains and steppes of newly-colonised overseas territories. Hardin's "tragedy of the commons" argument has some analytical value here (Hardin 1968), as short-term maximum returns from whaling and the hunting of buffalo in North America were almost completely unregulated.

As the modern banking system began to spread beyond its Italian origins in the early $15^{\text {th }}$ century, a sophisticated finance system emerged in Europe that provided the resources needed to engage in capital-intensive mining operations. From 1450 "mining, especially in central Europe, entered an age of progress unlike anything ever seen before" (Mokyr 1990: 63). This newly emerging form of capitalism went hand in hand with innovations in hydraulic engineering and smelting, which increased the rate of exploitation in the sector. The second great achievement of the early Renaissance period in applying its control over nature was in canal building, and especially in large-scale publicly funded drainage programmes that altered the landscape profoundly (Forbes 1958: 157).

The most devastating interference in the biosphere, however, was the ecological disaster caused by the introduction of exotic species to virgin environments outside Europe, disrupting natural equilibria and exterminating many native species, plants and animals alike. "Increased communications between different parts of the world also resulted in the spread of plant diseases and pests" (Ponting 1991: 175). Under the threat of exotic intruders, native plants quickly gave way to a wide variety of Eurasian species and this also paved the way for the success of European and MiddleEastern livestock (Crosby 1986: 145-170). This "ecological imperialism" illustrates another basic aspect of the ideology of domination: its connectedness to the domination by Europeans of other humans, as part of the territorial expansion of the major European powers. As Leiss (1974: 16) points out, "human activity becomes so much a part of the natural environment that mastery of nature and mastery of man are only two aspects of the same process". The maintenance of the Europeanised human ecologies of the New World would have been impossible without slave labour. The "rape of the world" (Ponting 1991: 161-192) preceded, and was co-determinous with, the exploitation of other cultures.

\section{Prerequisites for Change: Comparing Europe and China}

A puzzle that has occupied many thinkers, from Wolf to Braudel, is why Europe developed the necessary technologies, institutions and mental dispositions to dominate nature, over and above other civilizations. Europe was a cultural backwater until the end of the Middle Ages consisting of isolated and warring city-states and territories, and yet Western Europe then experienced a rapid take off. By comparison China, the most advanced civilization at this time, entered a phase of stagnation. Islamic civilization, formerly influential as far as southern Europe, had already declined in power by the 1400s. ${ }^{10}$ This problematic may be understood through an examination of geography, politics and culture.

According to Jones, Europe's advantage in comparison with China was its "ecological individuality". The contributing factors here were the presence of fewer and less devastating diseases due to relatively harsh winters, and the early development of ploughing technology (Jones 1987: 6). In addition, fewer natural disasters, like droughts and earthquakes, affected Europe than in other world regions (despite, of course, the presence of tectonic instability in Mediterranean that had affected the Greek and Roman empires). Favourable conditions made it possible for peasant farmers to apply a K-

\footnotetext{
$8 \quad$ An Act passed by the English Parliament in 1533 included foxes, polecats, weasels, stoats, otters, hedgehogs, rats, mice, moles, hawks, buzzards, ospreys, jays, raven and kingfishers in the list of unwanted animals.

9 For example, the Fugger's financial empire was built on mining activities in Hungary (cf. Rice and Grafton 1994: 52).

10 Compared to the China, the Islamic civilisation that influenced Europe so profoundly in the period between 1100 and 1400 was a borrower and chronist, but not so much an original inventor.
}

Journal of Political Ecology

Vol. 14, 2007 
strategy ${ }^{11}$ of population growth, controlling fertility by marriage restrictions and thus improving human capital (Jones 1987: 16). The greater frequency of natural disasters in China meant more uncertainty and risk, working against long-term investment. The capital-labour ratio in Europe "offered better protection for capital goods than for labour" than in China (Jones 1987: 39).

Political catastrophes like invasions and warfare also had a negative impact on capital investment. Western Europe's geographic location, a peninsula at the end of the vast Eurasian landmass, and its resulting seaward perspective were substantially different from China's landward orientation and its openness to the steppes of central Asia and their hostile cultures. Europe's relationship with the sea was instrumental in its emergence as a conquering civilisation, while China's maritime expeditions were more limited and considered a luxury in the context of imminent continental invasion.

Another explanation for Europe's relative advanced position in 1500 was its distinctive food regimes. Chinese aquatic rice production differed from the European agrarian system based around wheat, in its political, cultural, and economic consequences. The highly labour intensive paddy-field system required an enormous amount of labour and knowledge, tending towards (with some exceptions) a stable society, and state authority overseeing large-scale agrarian projects (Braudel 1982: 149). The result was a food regime that supported a strict social discipline and very limited social mobility. The high yields of rice agriculture permitted population growth, allowing more labour to be invested in intensive rice production, without exaggerating social stratification. In contrast, Europe went down a distinctively different path. The relatively small energy surplus of European agriculture was not so much directed towards population growth as towards livestock husbandry. The decision to favour animal protein over plant protein was decisive. In contrast to China's socially disciplined society and its large-scale works, Europe experienced social diversification among smallholders (see Netting 1993), and continuous competition for the production destined for an emerging market economy.

The same line of argument can be applied in the political arena. The competitiveness of the emerging European state system supported technological innovation and set the stage for the era of early capitalism. The contemporaneous ending of external shocks such as the Plague and the waning of feudalism in the $15^{\text {th }}$ century are of enormous importance for the political development of Europe (Jones 1987: 51). As monetary relations in markets replaced feudal ties, and the concept of individual property rights took hold within an emerging structure of general laws and practices, investments and long-distance trade became less risky. In sharp contrast, China's political organization was the empire. With its centralized decision-making processes the empire could easily obstruct important achievements, such as maritime expeditions. By the end of the $14^{\text {th }}$ century China possessed all the necessary technological requirements to engage in long-distant ocean transport, but despite the impressive accounts on the great commercial expeditions to the Indian Ocean between 1405 and 1433 - involving 250 vessels and thousands of men - the whole enterprise was abandoned by a single decision of the Imperial court (McNeill 1963: 526).

Officials and the landed interests proved superior against a weak and underdeveloped merchant class. China's bureaucratic feudalism, based on a class of civil servants, the Mandarinate, was the distinctive organizational feature of the Chinese political-administrative system. The Mandarins, the keepers of order, successfully checked and balanced the development of capitalism and maintained the unity of a vast empire against feudal lords, merchants, craftsmen, and peasants. In this way they were responsible for China's social immobility (Braudel 1993: 190). As Needham observes, "[a] predominantly mercantile order of society could never arise in Chinese civilisation because the basic conception of the Mandarinate was opposed not only to the principles of hereditary aristocratic feudalism but also to the value-system of the wealthy merchants" (Needham 1969: 197). After the end of the Mongol dynasty and its short-lived re-concentration on trade, the feudal-bureaucratic class was successful in reasserting the "fundamental Confucian principle, which classified merchants among the necessary evils of society" (McNeill 1963: 127). China's centralized empire and its powerful class of civil servants produced a political and economic immobility, while Europe was maturing as a region of competition and innovation.

The third context that may explain the different performance of Europe and China in regards to their economic and political-administrative developments, and subsequently their attitude towards nature, is cultural and philosophical. Social leadership depended on, according to the Confucian principles, learning and moral excellence, but not wealth (McNeill 1963:529). Upward social mobility was therefore based on educational achievement and was thus rather limited in scope compared to the post-

$11 \quad$ K-strategy organisms compete for survival, which requires investment of time and energy for the raising of offspring. This investment is only possible if the number of offspring is small. See Livi-Bacci (1997: 3).

Journal of Political Ecology

Vol. 14, 2007 
feudal environment in Europe, where the emerging territorial state, and its need for loyal servants, provided mobility.

Another explanation for the different paths Europe and China took after 1500 can be found in their radically opposed concepts of the laws governing nature. The idea that there were universal Laws of Nature that could be studied and predicted took hold in European philosophical tradition in the early $14^{\text {th }}$ century, after the death of Roger Bacon. The Chinese Taoist tradition, on the contrary, failed to develop anything resembling Laws of Nature because of a mistrust of reason and logic: "With their appreciation of relativism and the subtlety and immensity of the universe, they were groping an Einsteinian world-picture without having laid the foundations for a Newtonian one. By this path science could not develop" (Needham 1969: 311). This was the scientific framework that operated in China, while Europe was crossing the threshold to the scientific revolution of Humanism, the Renaissance, and prepared for its "great step ahead".

\section{Domination and Control: Europe's step ahead between 1450 and 1750}

Between 1450 and 1750 Europe acquired all the necessary technological, institutional and conceptual elements to develop its unique ideology of domination and control over the natural environment. This process may be analysed within four different contexts: first, the emerging early modern state; second, the legacy of the Judaeo-Christian tradition; third, the Scientific Revolution of the $17^{\text {th }}$ century; and finally the rise of early capitalism. Framed by the impacts of the Age of Discoveries and the end of a monolithic metaphysical explanatory structure caused by the onset of the Reformation, these interconnected institutions set the stage for the emergence of domination and control of nature as an integral part of European early modern culture.

The first decisive development in the context of the early modern state is the process of administrative concentration that took place between the mid $15^{\text {th }}$ and mid $16^{\text {th }}$ centuries. The balance of loyalties that had characterised feudalism shifted in favour of the Crown. It was during the same period that the "sovereign Prince" was widely appreciated as an absolute ruler, limited only by divine and natural law. Based on a new class of loyal servants that were no longer bound to the King by feudal ties but, rather, attracted by the promise of wealth and influence, the centralization of power helped to give birth to the early modern state. It was characterized by a standing army, an efficient bureaucracy, and the harmonisation of competing laws and standards. This created a framework of security that fostered capitalist development in the new territorial states, and thus increased the resource base on which state-building was based. As a result, power and control over financial, human, and natural resources vastly improved compared to Feudal times. The ideology of domination flourished within an institutional environment that was no longer based on a horizontal distribution of power, but on a vertical mechanism of command and control.

The domestic process of administrational concentration was accompanied by the formation of a competitive early modern state system, which also proved to be the ideal organizational structure for the rise of scientific and technological progress. Like a system of cells that influence and regulate each other in mutual ways (Jones 1987: 126) the European state system generated a momentum of technological innovation through a process of diffusion that would have been impossible under a less competitive institutional arrangement. It was precisely this European "genetic diversity" that proved superior over other political formations. Under these conditions the impact of war and other major catastrophes was lessened, and as trade continued through varying channels, economic development could not be restricted as easily as had been in centralized empires and civilizations. The competitive arrangement of the European state system and its dynamic consequences was the breeding ground for linear progress, which came to characterize European history and which shaped it so fundamentally.

The profound influence of a Judeo-Christian tradition on the western perception of nature was noted early in the debate about the causes of environmental degradation. Lynn White argues "the present increasing disruption of the global environment is the product of a dynamic technology and science which [...] cannot be understood historically apart from distinctive attitudes toward nature which are deeply grounded in Christian dogma" (White 1967). The Bible seems to indicate in various passages that nature was designed to meet human needs exclusively. The spirit is separated from nature and what matters is the individual relationship between God the creator and humans as his superior creatures. Unlike Animism, where nature itself is worshiped and praised, Christian belief segregates the sphere of sacredness from the natural environment, thus assigning it to the level of a supportive structure. The story of Creation is essentially a story of authorisation and legitimation. God transfers his unlimited authority over all the living creatures of the world to Man, making him the "Lord of nature". Since the time of the Renaissance this was, arguably, perceived as a political empowerment of the individual and it supported the concept of the King as an absolute ruler, legitimised by divine authority. 
The spread of Judeo-Christian culture into environments substantially different from its place of origin - the deserts and semi-arid zone of Palestine, for example - has also contributed to the dominant ideology of human-nature relations. As the simple and hostile environment of the JudeoChristian birthplace was abandoned for the more complex and resource-rich environment of northern Europe, without changing the basic perception of nature as an enemy to be defeated, the ideology of mastery over nature spread to regions where it could do substantial harm. ${ }^{12}$

But despite the many religious justifications of human authority over the earth and its creatures, Man did not perceive himself as an absolute ruler, but as God's loyal servant. As nature was God's creation, it was deemed sacred, and thus protected against destruction to a certain degree. It was only after secularisation took hold in Europe following the Reformation, that this safety valve broke down and allowed for the full-scale application of the disastrous ideology of control (Leiss 1974: 34). The Renaissance freed the mindset of domination from the limitations of religious dogma, but it failed to provide for a new ethic capable of regulating the relation between humankind and nature in the absence of a religious justification for the "rape of the earth". But the ties between God and nature were not entirely disconnected, because science took over the role of explaining human existence. Until the end of the $18^{\text {th }}$ century nearly every great scientist was preoccupied with religious problems, perceiving nature as the manifestation of the "grand clockmaker", God.

The work of Francis Bacon is an illuminating example of the embeddedness of scientific progress and the domination of nature in a religious context. "By casting his plea for scientific progress in a familiar religious mold, he managed to win wide acceptance for a novel conception of mastery over nature, and at the same time he unwittingly charted a course for later generations which led to the gradual secularisation of this idea" (Leiss 1974: 53). It was Bacon's achievement in formulating the concept of mastery over nature as a new scientific and practical enterprise (Russell 1961: 527). René Descartes' contribution to the development of modern science contains the deterministic segregation of mind and matter and the method of reductionism that led to a purely mechanistic worldview. This approach to scientific enquiry "inevitably led to a fragmented view of the world - to a focus on the individual parts of a system rather than on the organic whole, on studying the way in which the constituent elements operated separately rather than the ways in which they interacted" (Ponting 1991: 147). This resulted in the perception of humans and nature as governed strictly by the laws of physics, and thus it favoured the exploitation of the one by the other. It was Isaac Newton at the end of this essential phase of scientific development who transcended all these efforts by formulating an abstract and geometrised universe that was governed by the one fundamental principle of gravitation (Braudel 1993: 368). This substantial achievement enabled future generations of scientists to systemise the forces of nature into an abstract set of basic principles and rules, which resulted in a radical alienation of western civilisation from the notion of nature as a complex and mystical entity. ${ }^{13}$

Triggered by these rapid developments in science, a powerful new concept emerged on the stage of $17^{\text {th }}$ century Europe, the idea of progress. ${ }^{14}$ In strong contradiction to the classical conceptions of history as a constant gradual decline from a Golden Age, and to the Christian concept of history as a transitional phase between the creation of the world and the final judgement, the "early modern" view was one of continual improvement towards the full domination of nature by humankind (Ponting 1991: 150). It is in the ideas of Marx and Engels that the concept of inevitable progress of the human society has found its most influential manifestation.

The fourth substantial institution that contributed to the rise of the ideology of control and mastery over nature was the rise of early capitalism, prefigured by the Reformation and the rise of scientific discovery. Early capitalism - understood in contrast to the craft mode of production - splits the single class of artisans into two distinct social groups: entrepreneurs who own and control capital on the one hand, and waged workers on the other. By 1560 "the cleavage between capital and labour, which is - like scientific method and an art based on perspective - a unique peculiarity of western civilisation, was firmly and widely established in many parts of industrial Europe" (Rice and Grafton 1994: 60). But it was still the state who dominated early modern capitalism and who held the

12 For a more detailed account on the relation between the environment and the development of religion see Huntington (1972: 276-327).

13 However, the development of mechanistic science and the scientific Revolution of the 16th and 17th century were by no means linear. For example, the emerging discipline of botanics was initially characterised by its focus on utility (e.g. in the search for new herbal treatments), but developed into a less utility-oriented science during the 16th century. I am grateful to an anonymous reviewer for this observation.

14 For a more detailed account on the history of progress in the period of the great renewal (1560-1740), see Nisbet (1980: 118-170).

Journal of Political Ecology

Vol. 14, 2007 
institutional and financial powers to implement the new mode of production on a large scale. ${ }^{15}$ Its increasing demand for capital created the environment for broad private lending structures that profoundly influenced the development of early capitalism. This triggered the further consolidation of a highly influential merchant class, and its connected trade system, that developed rapidly in scale and scope and can be considered global by the late $16^{\text {th }}$ century.

The decisive new feature was not trade in itself, but the brutal pillage of the Americas that resulted in the accumulation of precious metals and the production of new value through cultivation of export crops (Beaud 2001). The developing trade in sugar and rum, which was based on a system of slave and forced labour, is an illustrative example of the very nature of the new ideology of domination that had enlarged its scope of application tremendously through exploration and colonisation.

The impact of this unique event has been twofold as far as our topic is concerned: First, the European economy became a European world economy ${ }^{16}$ (Wallerstein 1986: 447-514) and second, the discoveries served as an empty map for the collective imagination of Europe. The size of the New World and its abundant flora and fauna, which impressed the first explorers so profoundly, served as an imaginative space for Europe's expansion, having a substantial impact on the way in which the early Conquistas and settlers perceived their possibilities, both in regards to the land and the people. The enlargement of Europe's perspective relieved western culture of the disturbing necessity to confront itself with the growing degradation caused by its own distinct ideology of domination. The conquest was not only material and economic, but also mental in nature. The metaphor of the empty map can as well be utilised to describe the developments in science and technology: As religion lost its integrating power and the societal forces began to gravitate towards the edges it was the new scientific enterprise that provided an empty imaginative space for the collective hopes of Europe.

It was the Reformation, the second event exercising substantial influence on early modern times that induced this secular transition. But its impact goes far beyond this. There has been criticism of Max Weber's evocation of the Protestant Ethic as underlying the rise of capitalism, but the impact of the Reformation on economic development and competition in Europe after 1550 cannot be doubted. The recollection of the text as the central religious authority in Protestantism, and the reinstatement of Papal authority through the Jesuit order in Catholicism, did not halt the gradual process of secularisation, but it did provide yet another hidden authoritarian layer in European culture.

The slow development of capitalism - framed by the discoveries and the process of secularisation - did not reach its mature form, where surplus value was systematically extorted, until the end of the $18^{\text {th }}$ century (Beaud 2001). But it resulted in the enrichment of the bourgeoisie of Europe who became the agents of the fundamental change that altered Europe's face so profoundly, the French Revolution. As Herbert Muller phrased it, the "French Revolution brings us closer to the Industrial Revolution [...] as not only a political but a social revolution, ending once and for all the old aristocratic order with its feudal privileges, it marked the ascendancy of the bourgeoisie, who had taken charge of it" (Muller 1971: 42). The "new man" of the French Revolution is the true agent of the ideology of domination over nature, taking the decisive step towards industrialization and the finally the age of "post-historic man" (Mumford 1956: 154-176).

\section{Conclusion}

The ideology of domination over nature is still with us today; indeed it has submerged to deeper layers of consciousness, not only in western civilisation, but also to almost every culture on earth. Deeply rooted in our every-day beliefs, actions, reflections and hopes, it lies at the centre of any attempt to transform the world into a more loveable, friendlier, lighter and safer place. The enslavement of nature and the subsequent enslavement of humans by other humans has led to a global state of affairs that is neither morally nor practically sustainable. As the Nobel laureate Paul Crutzen has phrased it, humankind has entered a new phase in planetary history, the era of the "anthropocene". Consequently, any attempt to bring about change, whether on the micro or macro level or both, must take into account the complex history of development that lies behind the current situation.

This article has examined some of the historical processes and events that contributed to the very development of a European ideology of dominance, which has had such profound impacts on our interconnected world. Based on Europe's favourable situation in 1500, and framed by the scientific

15 The Venetian Arsenal represents one of the most paradigmatic early capitalist production structures in Europe.

16 A European world economy is not a global economy. Arguing that Japan was integrated into the European economy around 1600 is hard to prove (although there was trade between Europe and Japan), whereas the Brazil and the Azores were certainly strongly integrated.

Journal of Political Ecology

Vol. 14, 2007 
discoveries and the Reformation as central events, the ideology of domination over the natural environment took hold in the context of the competitive development of the European states system, the decline of Christianity as a total explanatory structure for human existence, the scientific turn of Cartesianism and the rise of capitalism to a self-replicating structure of rational choice.

In addition to making an argument about the specific conditions and prerequisites that led to the institutionalisation of an ideology of domination and control over nature, this article also contributes to the larger endeavour of embedding political ecology research in its historic context, while at the same time linking analysis of material developments to systemic ideational currents in world history.

\section{References Cited}

Beaud, $\mathrm{M}$.

A History of Capitalism. 1500-2000. New York: Monthly Review Press, 2001.

Braudel, F.

Civilization and Capitalism 15th-18th Century. The Structures of Everyday Life. The Limits of the Possible. New York: Harper \& Row, 1982.

Broswimmer, F.J.

A History of Civilisation. New York: Penguin, 1993.

Ecocide. A Short History of the Mass Extinction of Species. London: Pluto Press, 2002. Chew, S.C.

World Ecological Degradation: Accumulation, Urbanization, and Deforestation 3000 B.C. -

A.D. 2000. Lanham: Rowman \& Littlefield, 2001.

Crosby, A.W.

Ecological Imperialism. The Biological Expansion of Europe, 900-1900. Cambridge:

Cambridge University Press, 1986.

Forbes, R.J.

Man the Maker. A History of Technology and Engineering. London, New York: Abelard-

Schuman, 1958.

Greenberg, J.B. and T.K. Park

"Political Ecology." Journal of Political Ecology 1 (1994): 1-12.

Goudie, A.

The Human Impact On the Natural Environment. 5th ed. Oxford: Blackwell, 2000.

Hardin, G.

"The Tragedy of the Commons." Science 162 (1968): 1243-1248.

Huntington, E.

Mainsprings of Civilization. New York: Arno Press, 1972.

Jones, E.L.

The European Miracle. Environments, Economies and Geopolitics in the History of Europe and Asia. 2nd ed. Cambridge: Cambridge University Press, 1987.

Leiss, W.

The Domination of Nature. Boston: Beacon Press, 1974.

Livi-Bacci, M.

A Concise History of World Population. Cambridge, MA: Blackwell, 1997.

McNeill, W.H.

The Rise of the West. A History of the Human Community. Chicago: University of Chicago Press, 1963.

Mokyr, J.

The Lever of Riches. Technological Creativity and Economic Progress. Oxford: Oxford University Press, 1990.

Muller, H.J.

The Children of Frankenstein. A Prime on Modern Technology and Human Values.

Bloomington: Indiana University Press, 1971. 
Mumford, L.

The Transformation of Man. New York: Harper, 1956.

Needham, J.

The Grand Titration. Science and Society in East and West. Toronto: Toronto University Press, 1969.

Netting, R.

Smallholders, Householders. Farm Families and the Ecology of Intensive, Sustainable Agriculture. Stanford: Stanford University Press, 1993.

Nisbet, R.A.

History of the Idea of Progress. New York: Basic Books, 1980.

Ponting, C.

A Green History of the World. The Environment and the Collapse of Great Civilizations. New York: Penguin, 1991.

Rice, E.F. and A. Grafton

The Foundations of Early Modern Europe, 1460-1559. New York: W.W. Norton, 1994.

Russell, B.

History of Western Philosophy and its connection with political and social circumstances from the earliest times to the present day. London: Allen \& Unwin, 1961.

Wallerstein, I.

Das Moderne Weltsystem - Die Anfänge kapitalistischer Landwirtschaft und die europäische

Weltökonomie im 16. Jahrhundert. Frankfurt: Syndikat, 1986.

Wissenschaftlicher Beirat der Bundesregierung Globale Umweltveränderungen (WBGU)

Welt im Wandel: Neue Strukturen globaler Umweltpolitik. Berlin: Springer, 2001. White, L.

"The Historical Roots of Our Ecological Crisis." Science 155 (1967): 1203-1207.

World Watch Institute

Vital Signs 2002/2003. The Trends that are shaping our Future. London: Earthscan, 2002.

\begin{abstract}
:
This article contributes to the broadening agenda of critical globalisation(s) research by analysing one of the most fundamental ideological foundations of the current global transformation in a historical perspective: the ideology of "domination over nature" that was implemented in Europe from 1500 onwards. Humans have always shaped and altered their environment according to their needs and aspirations. However, it is the distinct ideology of mastery and domination over nature that underlines this unprecedented enterprise. An ideology in this context is understood as a codified justification for social practices, codified in concrete as well as highly abstract systems of rule. The question I seek to answer in this contribution is why Europe - a backward civilisation up to the late Middle Ages and the Renaissance - was the birthplace of the distinct ideology of mastery over nature, globalising itself through exploration, discovery, and trade to nearly every corner of the planet.
\end{abstract}

Key words: ideology of mastery, human-nature relations, ecological imperialism, historical political ecology 